\title{
The Effect of Water-Soluble Stem Extract "Kayu Kuning" (Arcangelisia flava L. Merr) On the Growth Inhibition of Candida albicans ATCC 10231 and Trichophyton mentagrophytes In Vitro
}

\author{
Rini Setyowati, Sudarsono* and Setyowati E. P \\ Faculty of Pharmacy UGM, Indonesia \\ Author correspondency*: \\ sudarsono@ugm.ac.id
}

\begin{abstract}
"Kayu kuning" (Arcangelisia flava L.Merr) was used when someone has a skin problem caused by Candida albicans and Trichophyton mentagrophytes. Scientific based medicine on this traditional knowledge was necessary be done. Stem powderwas extracted by distilled water.The extract was then evaporated. Qualitative and quantitative analysis of the active substance e.g., Berberin chloride by Thin Layer Chromatography (TLC) The antifungal activity againts Candida albicans and Trichophyton mentagrophyteswere tested by using agar diffusion and microdilution methods. The absorbance from microdilution were analized by One way ANOVA. The conclusion showed that the extract contained $1.55 \pm 0.12 \%$ w/walkaloid calculated as Berberine chloride. The inhibition zone for Candida albicans and Trichophyton mentagrophytes were $16.65 \pm 4.52$ and $6.55 \pm 0.05 \mathrm{~mm}$ respectively. The MIC vallue for both fungi was $10 \mathrm{mg} / \mathrm{mL}$. The MBC value for Candida albicans was $40 \mathrm{mg} / \mathrm{mL}$ and for Trichophyton mentagrophytes was $50 \mathrm{mg} / \mathrm{mL}$. From the analysis with one-way ANOVA, shows that there are significant differences between the positive control group and the test solution with the negative control group with $\mathrm{p}=0.020$ for Candida albicans and $\mathrm{p}=0.028$ for Trichophyton mentagrophytes $(\mathrm{p}<0.050)$. Post hoc Tukey analysis results showed that both intergroup and between the concentration of the test solution to the control group did not differ significantly positive because the value of $\mathrm{p}>0.050$.
\end{abstract}

Keywords: Arcangelisia flava L.Merr, "kayu kuning”, growth inhibitor, Candida albicans, Trichophyton mentagrophytes

\section{Introduction}

Candidiasis caused by C.albicans, water fleas and dermatophytosis caused by T.mentagrophytes. This infection disease is usually treated by azoles derivatives which are ketoconazol, fluconazol, miconazol, and also the poliena classes, such as nistatin, contemporarily for the dermatophyte can be treated by gryseofulvine (Jawetz et al., 2001). However, using antibiotic reported often causes microbes resistance (WHO, 2009). Indonesia has occupied on eight ranking out of 27 countries by heavy burden for Multi-drugs Resistancy/MDR around the world. According to Health Ministry of Republic of Indonesia (2011). The use of antibiotics for health service was often not appropriate, so it cause less effective treatment, increasing risk for the patients, widespread resistance and costly treatment. Therefore, it needs the proper solution to prevent the problems. One of solution is using traditional herbal medicine, as like conducted by remote communities that are far from goverment health services, so they can also conserve the local knowledge.

"Kayu kuning" or A. flavaL.Merr is one of plant used as traditional health care in the Suban Jeriji village, Rambang Dangku, Muara Enim, South Sumatra, Indonesia.This plant in Muna village, southeast Sulawesi is used for diarrhea, sore eyes, jaundice, oral ulces and water flea medicine (Larisu, 2011). This plant was known by its bright yellow wood's color, a herb, climbing, annual, wild growth and can be found in rocky beach or in edge of forest (Sitepu and Sutikno, 2001). A.flava L. contains saponin, flavonoid, polyphenolic substance, glycoside and alkaloid. Berberine derivative are the the main group found in this plant. It was reported by Singh, et. al. (2010). Whereas terpenes are found in this plant e.g., fibrauleusin, fibraurin (Siwon, 1982).Berberine is alkaloid in form of chloride or sulfate salts, they are existing on Menispermaceae plant, The mechanism of action as antimicrobial agent could be changing the arrangement of amino acid chain on DNA that rises balances changes of genetics on DNA, so that the DNA of microbial will be defeat, this causes a core of microbial cell to be defeat and dead (Dassonneville et al., 2000).

\section{Methodology}

\section{Materials}

Stem of A.flava L. was come from Suban Jeriji Village, Rambang Dangku, Muara Enim, South Sumatra. Voucher specimen was found at Pharmaceutical Biology Department, Faculty of Pharmacy UGM; berberine chloride (B2251-10G, Sigma), C.albicans ATCC 10231 and T.menta-grophytes, media nutrient broth and agar media, Nystatin, MTT (Methyl Thiazol Tetrazolium, Sigma), n-butanol, glacial acetic acid, distilled water, $0.9 \% \mathrm{NaCl}$ (Merck Germany) and TLC(Thin Layer 
Chromato-graphy) plates silica gel $60 \quad \mathrm{~F}_{254}$ (E.Merck Germany).

\section{Apparatus}

Set of reflux, incubator, autoclave, Laminair Air Flow (LAF), oven, flat microplate, microplate reader, petri dish, micropipette, white tip, yellow tip and blue tip, a set of tools Thin Layer Chromatography (TLC), Ultra violet (UV) light and TLC Scanner

\section{Procedure}

20 gram of drug powder was extracted by distilled water $100 \mathrm{~mL}$ for 2 hours (reflux). The water extract was was filtered evaporated by reduced vapor.

\section{Qualitative and Quantitative Analysis.}

It was done by TLC; $5 \mu \mathrm{L}$ test solution and berberine chloride were spotted on TLC plate on silica gel $60 \mathrm{~F}_{254}$. The mobile phase was n-butanol, acetic acid, water $(3: 1: 1$ $\mathrm{v} / \mathrm{v} / \mathrm{v})$. The spots were observed under $\mathrm{UV}_{254} \mathrm{~nm}, \mathrm{UV}_{366}$ $\mathrm{nm}$ and visible light. The spots of test substance and berberine chloride were scanned between 200 - $700 \mathrm{~nm}$. The standard curve ob berberin chloride was conducted from the series of berberine chloride, which was 100; 50; $25 ; 12,5$; and $6,25 \mu \mathrm{g} / \mathrm{mL}$. The solution test was made by $5 \mathrm{mg} / \mathrm{mL}$ in methanol. It was eluted by the same TLC system. The spot area under curve (AUC) that was suspected as alkaloid measured by densitometer. It was made standard curve by regressing content $(\mu \mathrm{g})$ vs area under curve. The alkaloid content was calculated as berberine chloride.

\section{Antifungal activities test by Agar Diffusion Method (Kirby-Bauer)}

The sterile agar media was diluted, after the lukewarm 10 $\mathrm{mL}$, the media was added by $100 \mu \mathrm{L}$ of fungi suspension, whipped homo-geneously. The concentration was $5 \times 10^{2}$ $2,5 \times 10^{3} \mathrm{CFU} / \mathrm{mL}$ of fungi in media. Mixture was poured into a sterile petri disk, waited until condensing. Steril paper diskwas mounted on the surface in order to be drop by sample $20 \mu \mathrm{L}$, each $10 \mu \mathrm{L}$ for nistatin and distilled water, then it was incubated on the temperature $37^{\circ} \mathrm{C}$ for 24 hours. Clear zone was measured by using vernier caliper.

\section{Anti-fungi test was done by microdillution method}

The test solution were dissolved into distilled water at several concentration $10 \% ; 8 \% ; 6 \% ; 4 \% ; 2 \% ; 1 \% ; 0,5 \%$; $0,25 \%$ and $0,125 \% \mathrm{~b} / \mathrm{v}$. Each $50 \mu \mathrm{L}$ solution test was poured into the well and added by fungi suspension in NB media. The fungi concentration becomes $5 \times 10^{2} \mathrm{CFU} / \mathrm{mL}$. The sample was incubated on $37^{\circ} \mathrm{C}$ temperature for 24 hours. Then, MTT was added to make easy observation. OD (Optical Density) value could be seen through the absorption. It could be computed by formula:
The clear pitting should be scratched on solid media for knowing a MEC value.

\section{Bioautographic Assay}

The solution test was spotted for $5 \mu \mathrm{L}$ on TLC plate and eluted by mobile phase n-butanol, acetic acid, water $(3: 1: 1 \mathrm{v} / \mathrm{v} / \mathrm{v})$. It was prepared the media in order to the sterile mixed by standardized fungi suspension, poured into sterile petri and wait until condensing. The TLC plate was eluted, and dried, then it should be placed on the media for 30 minutes. After TLC plate had been taken, incubated the petri disc by 24 hours on $37^{\circ} \mathrm{C}$. Their clear zone was observed.

\section{Results and Discussion}

Figure 1 showed that the $\mathrm{hR}_{\mathrm{f}}$ value of berberine chloride was 61 and spot like berberine solution test was 62 at visible light, UV $254 \mathrm{~nm}$ and $366 \mathrm{~nm}$. The spot of sampel and standard was yellow fluorescence under the UV 366 $\mathrm{nm}$. The scanning result for the two spots can be seen in Figure 2 at $\lambda_{\max } 349 \mathrm{~nm}$.

The standard equation curve was $\mathrm{y}=58596,5419 \mathrm{x}+$ 2512,5 with $\mathrm{r}$ value $=0,9956$. The berberine chloride solution test were $1,55 \pm 0,12 \% \mathrm{~b} / \mathrm{b}$ (Table 2 ).

The sample had antifungal activities for tested microbial. The complete activities as Table 3.

To know potential of extract for anti-fungi activities was conducted the potential test using liquid dilution method, which was micro-dilution. Parameter of antifungi activity was Minimum Inhibitory Consentration (MIC) value and Minimum Fungicidal Concentration (MFC). The smallest concentration that was still showing clearness was MIC, see Figure 4 and Table 4.

The standard equation curve was $\mathrm{y}=58596,5419 \mathrm{x}+$ 2512,5 with $\mathrm{r}$ value $=0,9956$. The berberine chloride solution test were $1,55 \pm 0,12 \% \mathrm{~b} / \mathrm{b}$ (Table 2 ).

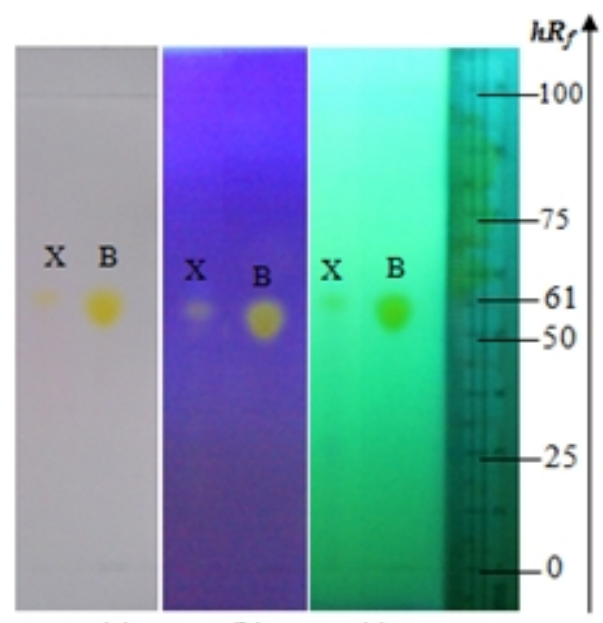

(a)

(b)

(c)

Figure 1. Chromatogram of water-soluble stem extract of A.flava (X) and berberine chloride (B) examination by: (a) visible light; (b) UV $366 \mathrm{~nm}$ and; (c) UV $254 \mathrm{~nm}$ Solid phase: silica gel 60 $\mathrm{F}_{254}$; mobile phase system: n-butanol, acetic acid, water $(3: 1: 1$ $\mathrm{v} / \mathrm{v} / \mathrm{v})$. 


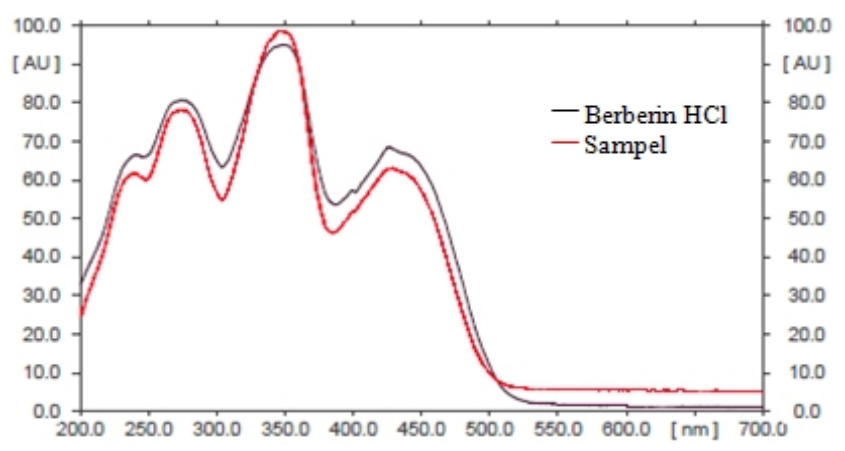

Figure 2. The pattern of UV Spectrum of Berberine chloride and sample test between 200-700 nm.
The sample had antifungal activities for tested microbial. The complete activities as Table 3.

To know potential of extract for anti-fungi activities was conducted the potential test using liquid dilution method, which was micro-dilution. Parameter of antifungi activity was Minimum Inhibitory Consentration (MIC) value and Minimum Fungicidal Concentration (MFC). The smallest concentration that was still showing clearness was MIC, see Figure 4 and Table 4.

Table 1. Berberine chloride content vsAUC.

\begin{tabular}{lllll}
\hline Berberinechloride $(\boldsymbol{\mu g} / \boldsymbol{\mu L})$ & volume $(\boldsymbol{\mu L})$ & Berberinechloride content $(\mathbf{n g})$ & hRf & AUC \\
\hline 0,00625 & 5 & 0,03125 & 63 & 2774,9 \\
0,0125 & 5 & 0,0625 & 63 & 6586,6 \\
0,025 & 5 & 0,125 & 63 & 10958,5 \\
0,05 & 5 & 0,25 & 63 & 17700,2 \\
0,1 & 5 & 0,5 & 63 & 31307,7 \\
\hline
\end{tabular}

Table 2. Berberinechloridecontent in water-soluble stem extract of "kayu kuning".

\begin{tabular}{|c|c|c|c|c|c|c|}
\hline $\begin{array}{l}\text { Sample consentration } \\
(\mathrm{mg} / \mathrm{mL})\end{array}$ & volume $(\mu \mathrm{L})$ & Sample weight $(\mu \mathrm{g})$ & hRf & $\mathbf{A U C}$ & $\begin{array}{l}\text { Berberinechloride } \\
\text { content/spot (ng) }\end{array}$ & $\begin{array}{l}\text { Content } \\
(\% \mathbf{o b} / \mathbf{b})\end{array}$ \\
\hline 5 & 5 & 25 & 63 & 25308,30 & 389,01 & 1,56 \\
\hline 5 & 5 & 25 & 64 & 23427,00 & 356,90 & 1,43 \\
\hline 5 & 5 & 25 & 64 & 26777,20 & 414,10 & 1,66 \\
\hline \multicolumn{4}{|c|}{ Average } & 25170,83 & 386,67 & 1,55 \\
\hline \multicolumn{4}{|c|}{$\mathrm{SD}$} & 1679,32 & 28,67 & 0,12 \\
\hline
\end{tabular}

Table 3. Diameter of inhabitation extract is for test microbial.

\begin{tabular}{|c|c|c|c|c|c|c|c|c|}
\hline \multirow[t]{2}{*}{ Solution } & \multicolumn{3}{|c|}{$\begin{array}{l}\text { Diameter inhibition C.albicans } \\
(\mathrm{mm})\end{array}$} & \multirow[t]{2}{*}{ average $(\mathrm{mm})$} & \multicolumn{3}{|c|}{$\begin{array}{l}\text { Diameter inhibition T.mentagrophytes } \\
(\mathrm{mm})\end{array}$} & \multirow[t]{2}{*}{ average $(\mathrm{mm})$} \\
\hline & 1 & 2 & 3 & & 1 & 2 & 3 & \\
\hline Sample & 13,73 & 21,53 & 13,68 & $16,31 \pm 4,52$ & 6,52 & 6,52 & 6,60 & $6,55 \pm 0,05$ \\
\hline Nystantin & 17,00 & 16,85 & 18,10 & $17,32 \pm 0,68$ & 7,50 & 7,75 & 8,00 & $7,75 \pm 0,25$ \\
\hline Aquadest & - & - & - & - & - & - & - & - \\
\hline
\end{tabular}

Table 4 showed that, the MIC value of sample were $1 \% \mathrm{w} / \mathrm{v}$ for C.albicans and T.mentagrophytes. While table 5 showed that the MFC of sample for C.albicans was $4 \% \mathrm{w} / \mathrm{v}$ and for T.mentagrophytes was $5 \% \mathrm{w} / \mathrm{v}$.

Result of Bioautography Assay showed that there was only an inhibition for C.albicans, but on T.mentagrophytes was not appearing the presence of a clear zone. TLC spot which was showing an activity of inhibition for C.albicans growth was the spot with $62 \mathrm{hRf}$ value. It was berberine chloride, as like appeared on Figure 5. This evidenced that solution test containing ...
... berberine chloride was a bio-active compound that was responsible for the presence of anti-fungi activities of C.albicans. While on T.mentagrophytes couldn't be determined if the compound has activity as anti-fungi, this should be caused by synergetic system. 
$\begin{array}{llllllllllll}1 & 2 & 3 & 4 & 5 & 6 & 7 & 8 & 9 & 10 & 11 & 12\end{array}$

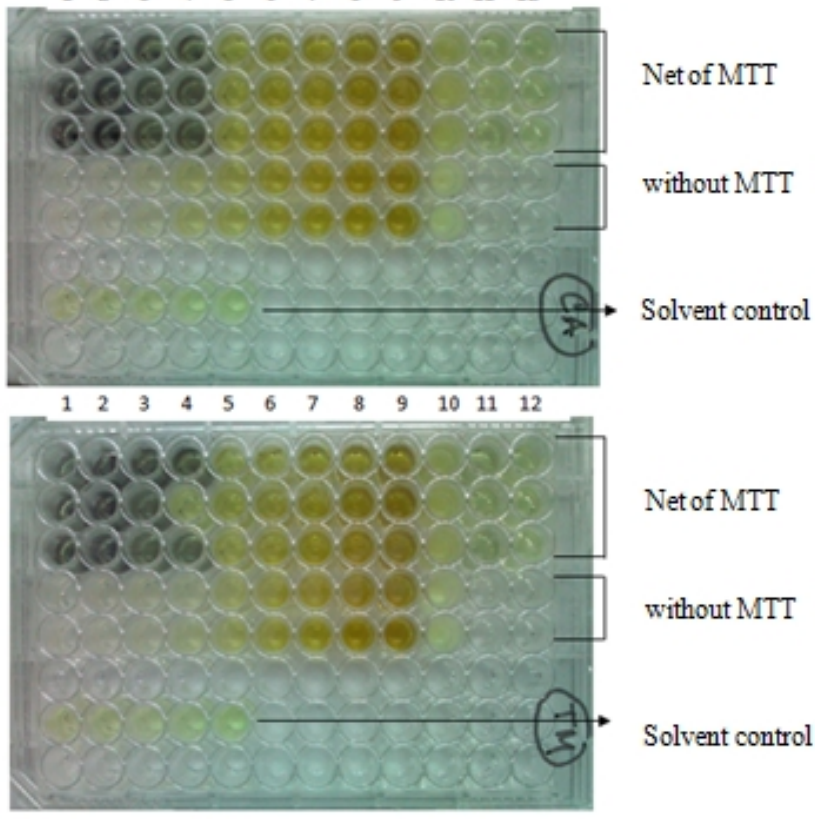

Figure 3. Microdilution for (a) C.albicans and (b) T.mentagrophytes using MTT reagent.

Table 4. MIC of sample for fungi tested using MTT reactant.

\begin{tabular}{lcccl}
\hline Fungi & \multicolumn{3}{c}{ MIC (mg/mL) } & $\begin{array}{l}\text { average } \\
(\mathbf{m g} / \mathbf{m L})\end{array}$ \\
\hline C.albicans & 10 & 10 & 10 & 10 \\
T.mentagrophytes & 10 & 10 & 10 & 10 \\
\hline
\end{tabular}

Table 5. MFC of sample for fungi tested.

\begin{tabular}{lcccccc}
\hline $\begin{array}{l}\text { Sample } \\
\text { Consentration } \\
(\% \text { w/v) }\end{array}$ & \multicolumn{3}{c}{ C.albicans } & \multicolumn{3}{c}{ T. mentagrophytes } \\
\cline { 2 - 7 } 1 & 1 & 2 & 3 & 1 & 2 & 3 \\
\hline 1 & + & + & + & + & + & + \\
3 & + & + & + & + & + & + \\
4 & + & + & + & + & + & + \\
5 & $-*$ & $-*$ & $-*$ & + & + & + \\
Nistatin5000 IU & - & - & - & - & - & - \\
control fungi & + & + & + & + & + & + \\
control media & - & - & - & - & - & - \\
control solvent & - & - & - & - & - & - \\
\hline Description: (+): There microbial growth \\
$(-):$ There is no microbial growth \\
$(*)$ MFC
\end{tabular}

From result of analysis using one way ANOVA, both C.albicans and T.mentagro-phyteswas exist significant differences between negative control group with all test solution group, this was by $\mathrm{p}$-value $=0,020$ for C.albicans, and $\mathrm{p}=0,028$ for T.mentagrophytes $(\mathrm{p}<0,05)$. This result showed that giving test solution causing the growth inhibition of microbial significantly. In addition to significant differences was also showed between positive control group and negative control both C.albicans and T.mentagrophytes tests.

Table 6. Percent inhibition of water-soluble extract of A.flava ("kayu kuning") against microbial test.

\begin{tabular}{cccc}
\hline \multirow{2}{*}{ No } & $\begin{array}{c}\text { Sample } \\
\text { consentration } \\
\text { (\% w/v) }\end{array}$ & \multicolumn{2}{c}{ Average of \% inhibition (\%) } \\
\cline { 3 - 4 } & 0,0625 & 67,16 & 48,22 \\
2 & 0,125 & 70,67 & 51,78 \\
3 & 0,25 & 73,9 & 65,21 \\
4 & 0,5 & 76,25 & 66,63 \\
5 & 1 & 77,13 & 74,67 \\
6 & $2 *$ & $85,92 *$ & $84,23 *$ \\
7 & 3 & 87,98 & 89,22 \\
8 & 4 & 92,38 & 93,39 \\
9 & 5 & 97,07 & 96,03 \\
Nistatin & 5000 IU & 100,22 & 100,41 \\
\hline Description: & (*): MIC & & \\
& & &
\end{tabular}

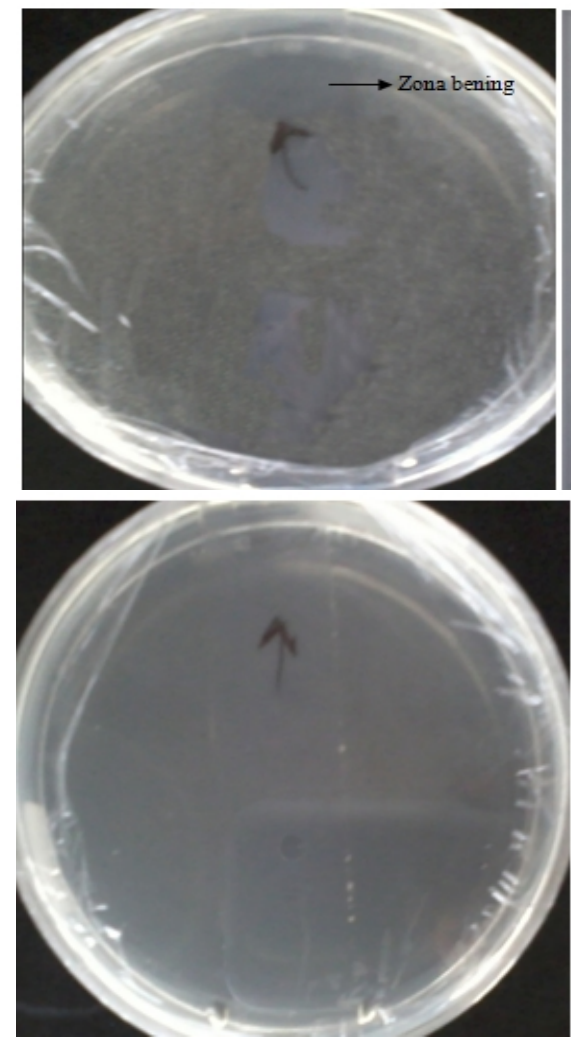

Figure 4. Bioautografi Assay results on (a) C.albicans T.mentagrophytes.

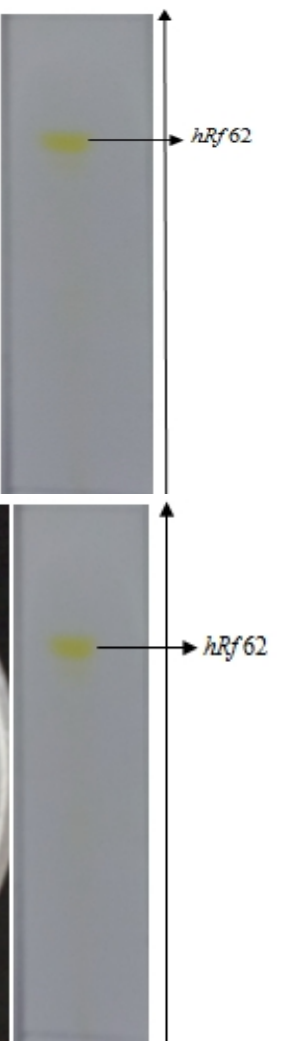

(b)
Analysis result of Post Hoc Tukey for C.albicans and T.mentagrophytes, correlation between positive control group and test solution group were not showing significant differences, except group number $1(0,0625 \%$ concentra-tion), that was by $\mathrm{p}>0,05$ value. This was showed that the test solution had the same effect with the positive control (antibiotic) for fungi growth. That was 
inhibiting the growth of fungi. While correlation between concentration groups on all test microbial, were not giving a significant differences, by $\mathrm{p}>0,05$ value. The data showed that an increasing of test solution concentration from the smallest concentration $0,0625 \%$ until $5 \% \mathrm{w} / \mathrm{v}$ were not showing a significant differences for the tested fungi growth inhibition.

An activity and potential of sample could inhibited C.albicans and T.mentagro-phytes growths that was caused by the compound contained in the extract, Berberine chloride. The activity of Berberine chloride was known as antimicrobial (Hwang et al., 2003; Karou et al., 2006; Scazzocchio et al., 2001; Swabb et al., 1981; Kaneda et al., 1991).

\section{Conclusion}

1. Water-soluble extract of "kayu kuning"(A.flava) was containing of $1.55 \pm 0.12 \% \mathrm{w} / \mathrm{w}$ alkaloid berberine chloride.

2. Water-soluble extract of "kayu kuning" (A.flava) was active as antifungal against C.albicans colony with MIC value of $10 \mathrm{mg} / \mathrm{mL}$ and MFC of $40 \mathrm{mg} / \mathrm{mL}$ while the colony T.mentagrophytes with $\mathrm{MIC}$ and $\mathrm{MBC}$ values of $10 \mathrm{mg} / \mathrm{mL}$ and $50 \mathrm{mg} / \mathrm{mL}$.

\section{References}

Backer, C.A., and Van den Brink, Jr.R.C.B., 1969, Flora of Java, Vol. I, 153, 157, N.V.P. Noordhoff, Groningen.

Chitwood, L. A., 1969, Tube Dilution Antimicrobial Sucseptibility Testing, Applied Microbiologi: 707-709.

Gupte, S., 1990, Mikrobiologi Dasar, Edisi III, diterjemahkan oleh Dr. Julius, E.S., 1992, 69-76, 321, BinarupaAksara, Jakarta.

Harborne, J. B., 1973, Metode Fitokimia, Penuntun Cara Modern Menganalisis Tumbuhan, diterjemahkan oleh Dr. Kosasih dan Dr. Iwang Soediro, 1984, Terbitan kedua, 234-245, ITB, Bandung.

Heyne, K. 1927, Tumbuhan Berguna Indonesia. Jilid II, diterjemahkan oleh Badan Litbang Kehutanan, 1987, Yayasan Sarana Wana Jaya, Jakarta.

Hwang, B.Y., Roberts, S.K., Chadwick, L.R., Wu C.D., and Kinghorn, A.D., 2003, Anti microbial Constituents from
Goldenseal (the rhizomes of Hydrastin canadensis) Againt Selected Oral Phatogens, Planta Med., 69 (7 : 623-627).

Karou, D., Savadogo, A.Yomeogo, S., and Montesano, C., 2006, Antibacterial activity of alkaloids from Sida acuta, J. Afric.Bio., 5 (2): 195-299.

Jawetz, E., Melnick, J.L., and Adelberg, E.A., 2001, Mikrobiologi Kedokteran, diterjemahkan oleh dr. Nani Widori, 2005, Edisi 22, 313-325, 344-346 Penerbit Salemba Medika, Jakarta.

Kaneda, Y., Torii, M., and Tanaka, T., 1991, In vitro effects of berberine sulfate on the growth of Entamoeba histolytica, Giardia lamblia and Trichomonas vaginalis. Ann. TroP. Med.Parasitol., 85:417-425

Keawpradub, N., Dejadisai, S. and Yuenyongsawad, S., 2005, Antioxidant and cytotoxic activities of Thai medicinal plants named Khaminkhruea: Arcangelisia flava, Coscinium blumeanum and Fibraurea tinctori, Songklanakarin, J. Sci. Technol., 27 (Suppl. 2) : 455-467.

Mahon, C. R., and Manuselis J.R. G., 1995, Textbook of Diagnosis Microbiology, W. B Sanders Company, Philadephia.

Nakamoto, K., Tamamoto, M., and Hamada, T., 1995, In vitro study on the effects of trial denture cleansers with berberine hydrochloride. J. Prosthet. Dent., 73:530-533.

Ongsangkul. M., Jindarat. A., and Rajona. C., 2009, Antibacterial /effect of Crude Alcoholic and Aqueous of Six Medical Plants Against Staphylococus aureus and Eschericia coli, J Health Res No. 23 Vol. 3 : 153-156

Praptiwi, Jamal. Y., Fathoni, A., and Agusta. A., 2009, Antimicrobial Metabolit From the Culture of Endophytic Fungus AFK-8 From Kayu Kuning (Archangelisia flava $L$. Merr), Research Centre of Biologi, Indonesian Institute of Science, Bogor.

Scazzocchio, F., Cometa, M.F., Tomassini, L., and Palmery, M., 2001, Antibacterial Activity of Hydrastis canadensis Extract and its Major Isolated Alkaloids, Planta Med., 67 (6): 561-564.

Schwalbe, R., Steele-Moore, L., and Goodwin, A.C., 2007, Antimicrobial Susceptibility Testing Protocols, 186-193, CRC Press Taylor \& Francis Group, London.

Singh, A., Duggal, S., Kaur, N., and Singh, J., 2010, Berberine: Alkaloid With Wide Spectrum Of Pharmacological Activities, J. Nat. Products, Vol.3:64-67.

Siwon, F., 1982, A Pharmacognostical Study of Some Indonesian Medicine of The Family Menispermaceae, Disertasi, 10, 43, Drukkij J H Pasmans B. V's Gravenhage.

Stahl, E., 1973, Analisis Obat secara Kromatografi dan Mikroskopi, diterjemahkan oleh Dr. Kosasih Padmawinata dan Dr. Iwang Soediro, 1985, Penerbit ITB, Bandung.

Swabb, E.A., Tai, Y.H., and Jordan, L., 1981, Reversal of cholera toxin-induced secretion inrat ileum by luminal berberine. $J$. Am. Physiol., 241 : 248-252. 
